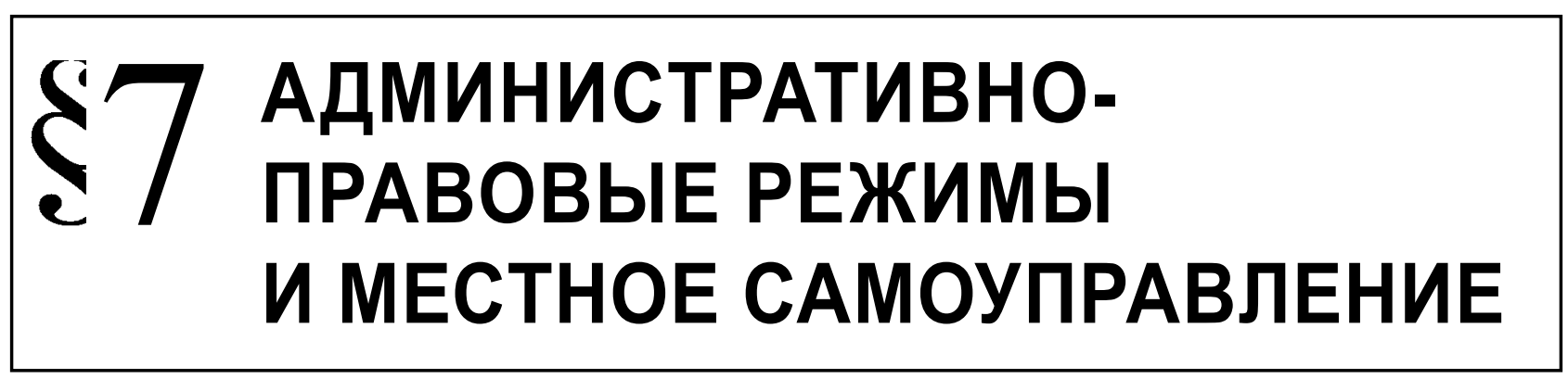

Беляева Г.С.

\title{
К ВОПРОСУ О ПОНЯТИИ ПРАВОВОГО РЕЖИМА
}

\begin{abstract}
Аннотация: В статье излагаются существующие в юридической науке подходы к определению понятия «правовой режим», позволяющие выработать его унифицированное авторское определение. Автором рассматривается этимология понятия "режим», его эволюция: зарождение исследуемой категории в трудах античных философов, дальнейшее ее развитие в работах зарубежных и отечественных ученых. Устанавливаются и характеризуются специфические признаки правового режима: обязательное нормативно-правовое закрепление; специфическая цель; особый порядок регулирования; создание благоприятных (неблагоприятных) условий для удовлетворения интересов субъектов права; системный и комплексный характер; особая структура правового режима. В работе использованы различные общенаучные приемы и способы логического познания: анализ и синтез, абстрагирование, моделирование, системно-структурный, функциональный и формально-логический подходы. Комплексный теоретико-прикладной междисциплинарный подход к исследованию правовых режимов обусловил необходимость использования в работе системного метода, в рамках которого осуществлено интегрирование теоретических абстракций, положений, закрепленных в действующем законодательстве, и эмпирических материалов правотворческой и правоприменительной практики. Данная статья имеет общетеоретический концептуальный характер, является комплексным междисциплинарным исследованием, направленным на разработку общей теории правового режима и повышение его эффективности. В рамках подготовленной работы автором осуществлен сравнительный анализ научных подходов к пониманию сущности и содержания категории "правовой режим", на основе чего выработано и предложено его унифицированное определение; выделены и охарактеризованы специфические признаки, позволяющие интерпретировать правовой режим в качестве самостоятельной юридической категории.
\end{abstract}

Ключевые слова: режим, правовой режим, понятие правового режима, признаки правового режима, цель правового режима, структура правового режима, правовые средства, порядок правового регулирования, дозволения, запреты.

$\Pi$ онятие правового режима широко используется в научной литературе, являясь одной государства и отраслевых науках. Оно весьма богато по содержанию и употребляется в различных смыслах и контекстах, однако общим является то, что оно олицетворяет функциональную характеристику права - определенный порядок правового регулирования, воплощаемый в комплексе правовых средств, с помощью которых достигаются его цели.

Вместе с тем, хотя названное правовое понятие подвергалось более или менее глубокому анализу уже давно и не раз, однако четкого представления о категории «правовой режим» так и не было получено.

Думается, что условно можно выделить три причины подобной ситуации.

Публикация подготовлена в рамках выполнения государственного задания Министерства образования и науки Российской Федерации по теме: «Юридическая деятельность и ее процессуальное обормление» (заявка 2014/78). 
Во-первых, в юридической литературе отсутствует единство мнений в отношении общетеоретической сущности правовых режимов.

Во-вторых, данная категория сравнительно недавно стала широко использоваться в различных отраслях права за пределами рамок административного управления и ведомственного нормотворчества.

И, как следствие, в-третьих, термин «правовой режим» относительно свободно и часто неоправданно используется законодателем в различных нормативно-правовых актах.

В итоге, несмотря на многообразие значений категории «правовой режим» в юридической литературе, она пока не получила полного освещения и, в основном, используется в различных отраслях права, как правило, применительно к характеристике объектов правового регулирования. Например, можно встретить такие определения правового режима применительно к объектам правового регулирования: «правовой режим информации это характеристика такого объекта правоотношений как информация, вытекающая из ее нематериальной природы» ${ }^{1}$.

Обозначенная проблема усугубляется еще и тем, что даже в рамках узкоотраслевых исследований понятие правового режима часто используется как «обиходное», уже известное и не нуждающееся в уточнении, а правовой режим нередко упоминается только в названии работы. В результате растет количество научных трудов, в которых данное понятие употребляется применительно к объектам правового регулирования (особенно в отраслях права), видам деятельности, субъектам права и т.д. подчас относительно свободно и часто неоправданно, без учета предназначения и истинной сущности рассматриваемой категории в системе правового регулирования.

Наряду с изложенным, широкое распространение категория «правовой режим» получила и в законодательстве. Так, Таможенный кодекс Таможенного союза оперирует такими понятиями, как режим наиболее благоприятствуемой нации, режим зоны таможенного контроля, режим экспорта и другие.

Имеют место и такие случаи, когда словосочетание «правовой режим» редко встречается в нормативно-правовых актах, но отраслевая наука и учебная дисциплина активно использует данный термин.

\footnotetext{
1 Терещенко Л.К. Правовой режим информации. Автореф. дис. ... докт. юрид наук. М., 2011. С. 16.
}

Примером может служить наука и учебная дисциплина «Земельное право», где часто встречаются такие понятия, как «правовой режим земель сельскохозяйственного назначения», «правовой режим земель населенных пунктов», «правовой режим земель особо охраняемых территорий и объектов» и другие в то время, когда законодатель их использует не так часто ${ }^{2}$. С нашей точки зрения, в данном случае можно говорить об оправданном использовании изучаемой категории, поскольку правовые средства, гарантии и принципы в рамках правового регулирования данной группы отношений, объединяясь, формируют именно правовой режим ${ }^{3}$.

Конституционный Суд Российской Федерации в своих постановлениях и определениях также широко использует термин «правовой режим», причем и в тех случаях, когда исследуемый судом нормативный материал не содержит данного словосочетания. Например, Определение Конституционного Суда РФ от 11.05.2012 № 836-0 «Об отказе в принятии к рассмотрению жалобы гражданина Шатобы Александра Борисовича на нарушение его конституционных прав положениями пункта 3 статьи 15 Федерального закона «0 безопасности дорожного движения» указывает, что отнесение транспортных средств к источникам повышенной опасности обусловливает необходимость установления для них особого правового режима в целом и специальных правил их допуска к эксплуатации в частности. Кроме того, в правовых актах Конституционного суда РФ применительно к характеристике правовых режимов можно встретить такие словосочетания, как «конституционно-правовой режим применения норм права» 5 ,

\footnotetext{
2 Так, Земельный кодекс РФ оперирует понятием «правовой режим» не более, чем в 10 нормах.
}

3 Заметим, что региональное законодательство и акты федеральных органов исполнительной власти чаще используют словосочетание «правовой режим земель» // См., напр.: «Технические требования к плану участка» (утв. Роскомземом от 11.06.1993) // Закон. 1993. № 7; Приказ Минкультуры РФ от 11.11.2011 № 1055 «Об утверждении формы паспорта объекта культурного наследия» (Зарегистрировано в Минюсте РФ 01.12.2011 № 22471) // Бюллетень нормативных актов федеральных органов исполнительной власти. 2011. № 51; Распоряжение Комитета по государственному контролю, использованию и охране памятников истории и культуры Правительства СанктПетербурга от 12.07.2004 № 10-2 «О подготовке заключений о правовых режимах земельных участков» (документ опубликован не был)// СПС «Гарант».

4 Документ опубликован не был // СПС «Гарант».

5 Определение Конституционного Суда РФ от 07.02.2012 № 234-О-Р «Об отказе в принятии к рассмотрению хода- 
«особый правовой режим приобретения, осуществления и прекращения статуса судьи» ${ }^{6}$, «единый режим административной ответственности» ${ }^{7}$ и другие.

Таким образом, правовой режим - многозначное, межотраслевое и междисциплинарное понятие, правомерно используемое в различных областях научного знания и в текстах нормативноправовых актов, которое прочно вошло в юридическую терминологию и общественно-политический лексикон для обозначения различных правовых состояний в общей теории права и ряде юридических отраслей (административном, земельном, экологическом и др.).

Как точно отмечает Ю.А. Кудрявцев, «многозначность понятия «режим» свидетельствует о его междисциплинарности, о том, что оно используется в различных областях научного знания. В наибольшей же степени оно применяется в политико-правовых исследованиях, так как позволяет гораздо глубже и полнее раскрыть состояние современного общества, характер происходящих в нем перемен».

В то же время понятие правового режима остается одним из наименее изученных и наиболее сложных в правоведении, представляя обширное поле для научных дискуссий о его универсальности, сущности, предназначении и характере правовых режимов. Думается, что иначе, как парадоксальной, эту ситуацию назвать нельзя.

Таким образом, в целях преодоления узкоотраслевого понимания правовых режимов (по

тайства Совета народных депутатов Кемеровской области о разъяснении Определения Конституционного Суда Российской Федерации от 4 декабря 2007 года N 828-О-П» (документ опубликован не был)// СПС «Гарант».

6 Постановление Конституционного Суда РФ от 20.07.2011 № 19-П «По делу о проверке конституционности положений пунктов 1 и 2 статьи 3, пункта 1 статьи 8 и пункта 1 статьи 12.1 Закона Российской Федерации «О статусе судей в Российской Федерации» и статей 19, 21 и 22 Федерального закона «Об органах судейского сообщества в Российской Федерации» в связи с жалобой гражданки А.В. Матюшенко» // СЗ РФ. 2011. № 31. Ст. 4809.

7 Определение Конституционного Суда РФ от 14.07.2011 № 1031-О-О «Об отказе в принятии к рассмотрению жалобы гражданина Березовского Анатолия Алексеевича на нарушение его конституционных прав примечаниями к статье 16.1 Кодекса Российской Федерации об административных правонарушениях» (документ опубликован не был) // СПС «Гарант».

8 Кудрявцев Ю.А. Демократия как разновидность политического режима (теоретико-правовой аспект). Автореф. дис.... канд. юрид. наук. СПб, 2002. С. 9. сути, сведения их к определению объектов права) и нередко произвольного использования этого термина в текстах нормативно-правовых актов и в научных исследованиях существует объективная необходимость постановки проблемы изучения правовых режимов как фундаментального общетеоретического направления.

С нашей точки зрения, в целях унификации представлений о сущности правового режима целесообразно вначале обратиться к первоначальному смыслу слова «режим», что даст возможность вывести логичное определение этого термина и позволит оценить обоснованность его использования в науке и законодательстве.

В переводе с французского языка régime oзначает диету, строй, укладэ; власть, систему ${ }^{10}$. В переводе с латинского regimen есть управление; командование, начальствование; заведование, руководство, управление ${ }^{11}$.

Можно определить следующие группы смыслового значения понятия «режим»:

а) государственный строй, совокупность, средств, методов и способов осуществления власти, характеризующая политическую обстановку в стране ${ }^{12}$;

б) точно установленный распорядок жизни (труда, отдыха и т.д.);

в) система правил, мероприятий, необходимых для той или иной цели (режим безопасности на производстве) $)^{13}$.

Из изложенного следует вывод о том, что главное назначение режимов вообще (пока безотносительно к режиму правовому) состоит в обеспечении с помощью различных средств, методов и способов определенного социального или технического порядка (распорядка).

Теперь перейдем к непосредственному рассмотрению понятия правового режима, и для более полного его осмысления обратимся к историографии рассматриваемого термина.

Примечательно, что возникает понятие «правовой режим» еще в древние века. Так, А.В. Игнатенко отмечает, что уже в трудах Аристо-

\footnotetext{
9 http://www.jiport.com

10 http://lingvo.yandex.ru

11 http://lingvo.yandex.ru

12 Данная характеристика относится к государственным и политическим режимам. См.: Юридический энциклопедический словарь / Гл. ред. А.Я. Сухарев. М., 1984. С. 319.

13 См.: Словарь русского языка. Том 3. М., 1984. С. 697.
} 
теля, Платона, Панетия, Полибия, Лукреция, Цицерона, в их учениях о трёх основных государственных формах (монархии, аристократии, демократии), о развитии этой эволюционной цепи и отклонениях от «правильных» форм (тирания, олигархия, охлократия) можно найти зачатки представлений о явлениях, составляющих политический режим ${ }^{14}$.

Эволюция подходов к исследуемому понятию наблюдается в трудах Т. Мора, Т. Кампанеллы, Г. Бабеф $\mathrm{a}^{15}$ и связана с идеей утверждения нового режима государственного управления - режима диктатуры трудового народа.

Теории и концепции правовых режимов разрабатывались также в учении о праве войны и мира Г. Гроция ${ }^{16}$, теории государства Т. Гоббса ${ }^{17}$, теории разделения властей Ш. Монтескье ${ }^{18}$, теории общественного договора Ж.-Ж. Руссо ${ }^{19}$, учении о праве И. Канта ${ }^{20}$, философии права Г.В.Ф. Гегеля ${ }^{21}$, учениях о пределах государственной деятельности В. Гумбольдта ${ }^{22}$, о «борьбе за право» Р. Иеринга ${ }^{23}$, o социальном преобразовании права и государства Л. Дюги ${ }^{24}$, о конституции и суверенитете государства К. Шмита ${ }^{25}$, институциональной теории публичного права М. Ориу ${ }^{26}$ и т.д., где категория «правовой режим» рассматривалась в контексте эволюции государства и права.

В отечественной науке концептуальное осмысление категории «правовой режим» прослежи-

14 См.: Игнатенко А.В. Формирование аристократического режима в Риме. Свердловск, 1987. С. 39.

15 См. подробнее: Антология мировой философии. В 4-х т. М.: Мысль, 1970.

16 Гроций Г. О праве войны и мира. - М., 1994.

17 Гоббс Т. Левиафан, или Материя, форма и власть государства церковного и гражданского. - М., 1936.

18 Монтескье Ш. Трактат о разделении властей//Избранные произведения. М., 1955.

19 Руссо Ж.-Ж. Трактаты. М., 1969.

20 Кант И. Основы метафизики нравственности. Сочинения в 6 т. М., 1965.

21 Гегель Г.В.Ф. Философия права. М., 1990.

22 Гумбольдт В. О пределах государственной деятельности, M., 2003.

23 Иеринг Р. Борьба за право. М., 1991.

24 Дюги Л. Социальное право, индивидуальное право и преобразование государства // Право и жизнь, 2000. № 32-36.

25 Шмит К. Политическая теология. Сборник. М., 2000.

26 Ориу М. Основы публичного права. М., 1929. С. 658. вается в трудах С.А. Муромцева ${ }^{27}$, Л.И. Петражицко$\Gamma^{28}$, Н.М. Коркунова ${ }^{29}$, Г.Ф. Шершеневича ${ }^{30}$.

Исторический срез проблемы свидетельствует, что категория «правовой режим» получила первоначальное развитие в государствоведении, и лишь позднее стала объектом научного исследования теории права.

В советской юридической литературе 50-х годов XX века названная категория использовалась исключительно для характеристики законности. Так, Н.Г. Александров и С.Г. Березовская определяли советскую законность не просто как исполнение законов, а как особый режим, характеризующийся неуклонным соблюдением законов ${ }^{31}$, что впоследствии привело к фактическому отождествлению советской законности и правового режима ${ }^{32}$.

Данное мнение было подвергнуто критике в трудах И.С. Самощенко, точка зрения которого сводилась к следующему: «правовой режим» - это правопорядок; определять законность как правовой режим - значит терминологически отождествлять её с правопорядком» ${ }^{33}$.

В качестве аргумента также приводилось высказывание В.И. Ленина, который употреблял термин «правовой режим» именно в смысле правопорядка ${ }^{34}$, а потому говорил о законности, как об отличном от него явлении.

Только в 60-е годы XX века в работах, посвященных теме правового регулирования, получает развитие и понятие «правовой режим» в контексте сочетания типов правового регулирования ${ }^{35}$.

27 Муромцев С.А. Определение и основное разделение права. СПб., 2004. С. 224.

28 Петражицкий Л.И. Теория права и государства в связи с теорией нравственности. Т. 1. СПб., 1909.

29 Коркунов Н.М. Лекции по общей теории права. СПб., 1904.

30 Шершеневич Г.Ф. Общая теория права. М., 1911. С. 376.

31 См.: Александров Н.Г. О роли советского социалистического государства и права в развитии советского общества: Учебное пособие по теории государства и права. Вып. 1. М., 1953. С.21; Березовская С.Г. Прокурорский надзор в советском государственном управлении. М., 1954. С. 9.

32 Александров Н.Г. Законность и правоотношения в советском обществе. М., 1955. С. 68.

33 Самощенко И.С. Охрана режима законности советским государством. М., 1966. С. 13.

34 Ленин В.И. Полн. собр. соч. Т.17. С. 249.

35 См., напр.: Алексеев С.С. Механизм правового регулирования в социалистическом государстве. М., 1966; Иоффе О.С. Юридические нормы и человеческие поступки // Актуальные проблемы советского гражданского права. М., 1964. С. 16-26. 
В современном своем значении изучение в юридической литературе проблематики правовых режимов совпало по времени с началом периода правового реформирования на рубеже $90-\mathrm{x}$ гг. XX века, в основе которого был заявлен переход к новому качеству правового регулирования.

Первоначально речь шла о поиске специальных механизмов, способных в рамках законодательного (в противовес подзаконному, ведомственному) регулирования обеспечить решение насущных проблем, стабилизировать социальноэкономические процессы, ограничить влияние негативных факторов как субъективного, так и объективного характера.

Именно в это время в качестве специально организованного механизма, способного к самостоятельному решению поставленных перед ним задач, отличающегося стабильностью, и в то же время динамичностью, возможностью своевременно реагировать на отклонения в социальной ситуации и предотвращать сбои в правовом регулировании, был предложен правовой режим.

Необходимо отметить, что относительно определения правового режима в настоящее время существует несколько основных подходов.

Согласно первому из них, правовой режим определяется как «социальный режим некоторого объекта, закрепленный правовыми нормами и обеспеченный совокупностью юридических средств» ${ }^{36}$.

Полагаем, что недостатками данного подхода следует признать использование слова «режим» в качестве определяющего и некоторую нечеткость в самом определении. Однако в данном определении содержится указание на социально-правовой характер и структурные элементы правового режима: нормы права и другие «юридические средства», которое позволяет сразу же отграничить правовой режим от ряда других общетеоретических категорий, сводимых лишь к совокупности правовых норм. Тем самым правовой режим выступает особой юридической категорией, специфическим средством правового регулирования, объединяющим в себе правовой инструментарий в комплексе.

Приведенное выше определение правового режима как совокупности юридических средств справедливо и для «режима правового регулирова-

36 Исаков В.Б. Механизм правового регулирования и правовые режимы // Проблемы теории государства и права / Под ред. С.С. Алексеева. М., 1987. С. 258-259. ния» (термин С.С. Алексеева), под которым данный автор понимает «особую систему регулятивного воздействия, характеризующуюся специфическими способами регулирования - особым порядком возникновения и формирования содержания прав и обязанностей, их осуществления, спецификой санкций, способов реализации, а также действием единых принципов, общих положений» ${ }^{37}$.

В этом случае наблюдается более глубокий анализ проблемы, что проявляется, прежде всего, в обращении не только к структуре правового режима, но и к особенностям его характера.

Одновременно заметим, что С.С. Алексеев предлагает также еще одну характеристику правовых режимов, воспринятую другими учеными как традицию, основу которого составляет восприятие правового режима в качестве «порядка регулирования, выраженного в комплексе правовых средств, характеризующих особое сочетание взаимодействующих между собой дозволений, запретов, а также позитивных обязываний и создающих особую направленность регулирования» ${ }^{38}$.

Такая характеристика составляет сущность второго подхода к определению правового режима, воспринятая и более поздними исследователями проблемы. Так, Б.Я Бляхман определяет правовой режим как порядок регулирования, который выражен в комплексе правовых средств, характеризующих особое сочетание взаимодействующих между собой дозволений, запретов, а также позитивных обязываний и создающих особую напряженность регулирования ${ }^{39}$.

По нашему мнению, среди достоинств данного определения - удачное использование подходящего определяющего термина «порядок», а также углубление в суть явления; в нем подчеркнуто сочетание в режиме императивного и диспозитивного методов как основных средств воздействия насубъектов права.

В то же время при таком подходе из поля зрения С.С. Алексеева уходит такой существенный материальный признак правового режима как степень его благоприятности (неблагоприятности) для субъектов права. При этом сам ученый признает, что «каждый правовой режим есть все же

\footnotetext{
37 Алексеев С.С.Общая тория права в 2 томах. Т. 2. М., 1981. C. 245

38 Алексеев С.С. Общие дозволения и общие запреты в советском праве. М., 1989. С. 185.

39 См.: Бляхман Б.Я. Правовой режим в системе регулирования социальных отношений. Кемерово, 1999. С. 16.
} 
именно режим; следует принимать во внимание основные смысловые оттенки этого слова, в том числе и то, что правовой режим выражает степень жесткости юридического регулирования, наличие известных ограничений или льгот...» ${ }^{40}$.

В рамках второго подхода заслуживает также внимания позиция В.К. Бабаева, В.М. Баранова и В.И. Гоймана, по мнению которых, правовой режим - качественно целостная специфическая система средств, приемов, методов правового регулирования, которая выражается в особенностях нормативно-правовых отношений и индивидуальных предписаний, возникновения правоотношения, юридических последствий, способов обеспечения реализации требований права. Это такой порядок регулирования, который выражен в комплексе правовых средств, создающих особую направленность регулирования и характеризующих особое сочетание взаимодействующих между собой дозволений, запретов, а также позитивных обязываний ${ }^{41}$.

Данное определение, по нашему мнению, учитывает основные признаки правового режима, ориентировано на организационно-правовое и организационно-техническое обеспечение режимных требований. Однако, принимая во внимание его некоторую громоздкость, следует отметить, что при достаточно обширном анализе различных сторон проблемы позиция авторов нуждается в определенной корректировке.

Методологически близкой к вышеизложенной позиции является и точка зрения Э.Ф. Шамсумовой, анализирующей «правовой режим» в двух значениях: в широком смысле - как особый порядок законодательного урегулирования деятельности, действий или поведения физических и юридических лиц в различных сферах общественных отношений либо на определенных объектах, включающий в себя установление механизма обеспечения фактической реализации системы дозволений, стимулов, нормативов, гарантий, запретов, ограничений, обязываний, а также их компетентное исполнение и применение мер принуждения и привлечения виновных к ответственности; в узком смысле - это закрепленное в нормах права особое сочетание юридического инструментария (юридических средств), характеризующееся наличием определенных условий, конкретностью

\footnotetext{
40 Алексеев С.С. Теория права. 2-е изд. М., 1995. С. 244.

${ }_{41}$ Бабаев В.К., Баранов В.М., Гойман В.И. Словарь категорий и понятий общей теории права. Н.Новгород, 1992. С. 29.
}

(определенностью) общественных отношений, относительностью к определенному объекту и преследующее благоприятную, полезную для общества и государства цель ${ }^{42}$.

Однако следует заметить, что данное определение, с нашей точки зрения, не лишено логических противоречий (например, использование через запятую синонимичных понятий «деятельность, действия, поведение»), неточностей (упоминание в определении только физических и юридических лиц фактически изымает из-под действия правовых режимов субъекты, не являющиеся юридическими лицами, - некоторые общественные объединения, филиалы и представительства юридических лиц и т.д.), разночтений (использование в одном ряду такихпонятий, как «дозволения, стимулы, нормативы, гарантии, запреты, ограничения, обязывания», где понятие нормативов объединяют в себе все остальные понятия) и некоторых других.

Еще одним вариантом дефиниции правового режима в рамках вышеназванного подхода является предложенное А.П. Ситниковым его определение как «самостоятельного правового средства государства, используемого в целях обеспечения безопасности граждан и защиты конституционного строя, как специализированного порядка деятельности субъектов права, предназначенного для решения специфических задач или функционирования публично-властных субъектов в особых обстоятельствах ${ }^{43}$.

В данном случае ученый, раскрывая понятие правового режима, совершенно верно указывает на его инструментальную природу, цели и задачи. В то же время нельзя не заметить следующее: хотя автор прямо говорит, что дает определение именно общеправовой категории ${ }^{44}$, акцент в нем смещен все же в публично-правовую сферу.

В рамках третьего направления Л.А. Морозовой под правовым режимом понимается результат регулирующего воздействия на общественные отношения систем (определенного набора) юридических средств, присущих конкретной от-

\footnotetext{
42 См.: Шамсумова Э.Ф. Правовые режимы (теоретический аспект): Дис. ... канд. юрид. наук. Екатеринбург, 2001. С.72, 78 .

43 Ситников А.П. Вопросы соотношения категорий «правовой режим», «правовое состояние» и «правовой порядок» // Вестник Челябинского государственного университета. 2009. № 31 (169). Право. Вып. 21. С. 9-11.

44 Там же. С. 11.
} 
расли права и обеспечивающих нормальное функционирование данного комплекса общественных отношений ${ }^{45}$.

Сходную точку зрения высказывает и В.А. Горленко, который утверждает, что в правовой науке сложилось два основных подхода к исследуемому понятию. По его мнению, первая группа ученых полагает, что правовой режим есть результат государственного волеустановления и одновременно социальный порядок, сложившийся вследствие объективно существующих общественных отношений. Другие считают, что правовой режим это порядок, специально установленный государством в целях регулятивного воздействия на поведение субъектов социальных отношений юридическими средствами и методами ${ }^{46}$. Сам В.А. Горленко присоединяется к позиции первой группы и уточняет, что это еще и нормативный порядок, являющийся средством достижения конкретных целевых установок, который осуществляется при помощи юридических (правовых) средств и методов, направленных на реализацию правил поведения, закрепленных в правовых нормах, а также на осуществление мер юридической ответственности ${ }^{47}$.

Безусловно, и в этом можно согласиться с Л.А. Морозовой и В.А. Горленко, правовой режим выступает результатом нормотворческой деятельности, но можно ли назвать его закреплением уже существующих связей? Предпримем попытку ответить на этот весьма важный вопрос.

Как известно, являясь воплощением нормативности права, правовой режим вводится для обеспечения главного социального назначения права регулирования общественных отношений. Регулятивная функция права реализуется через свои разновидности - регулятивную динамическую и регулятивную статическую. В основе первой правовые нормы, направленные на обслуживание юридическими средствами тех или иных социальных процессов, вторая - реализует ту часть социального назначения права, которая заключается в закреплении средствами права определенных статусов в обществе, обеспечении стабильности социально-правовых ценностей.

45 См.: Морозова Л.А. Конституционное регулирование в CССР. М., 1985. С. 123.

46 См.: Горленко В.А. Режим правового регулирования (теоретико-прикладной аспект).Автореф. дис. ... канд. юрид. наук. СПб, 2002. С. 5.

47 Там же. С.6.
Следовательно, правовой режим должен интегрировать в себе, как минимум, две крупные подсистемы: систему регулятивного воздействия комплекс юридических средств, соподчиненных в рамках правовой отрасли с соответствующим методом правового регулирования (так называемый динамический аспект), а также результат регулирующего воздействия - достигнутый уровень урегулированности общественных отношений, который проявляется в определенном положении субъектов (объектов) права (так называемый статический аспект).

Заметим, что с критикой предложенного Л.А. Морозовой определения правового режима выступают Н.И. Матузов и А.В Малько: «правовой режим - это не столько результат, сколько система условий и методик осуществления правового регулирования, определенный «распорядок» действия права, необходимый для оптимального достижения соответствующих целей» ${ }^{48}$.

Своеобразным «синтезированным» определением правового режима, разработанным с учетом положительных и отрицательных моментов ранее рассмотренных точек зрения, можно считать позицию Н.И. Матузова и А.В. Малько, ориентированную на функциональную характеристику права: «правовой режим есть особый порядок регулирования, выражающийся в определенном сочетании юридических средств и создающий желаемое социальное состояние и конкретную степень благоприятности либо неблагоприятности для удовлетворения интересов субъектов права» ${ }^{49}$.

Аналогичное определяется правовой режим и О.С. Родионовым: «правовой режим - это установленный законодательством особый порядок регулирования, представленный специфическим комплексом правовых средств, который при помощи оптимального сочетания стимулирующих и ограничивающих элементов создает конкретную степень благоприятности либо неблагоприятности в целях беспрепятственной реализации субъектами права своих интересов» ${ }^{50}$.

Позитивным является то, что в указанных определениях правовых режимов уже содержатся

48 Матузов Н.И., Малько А.В. Правовые режимы: вопросы теории и практики // Известия вузов. Правоведение. 1996. № 4. C. 17-18.

49 Там же.

50 Родионов О.С. Механизм установления правовых режимов российским законодательством. Дисс. ... канд. юрид. наук. Саратов, 2001. С. 38. 
их основные сущностные характеристики и выделяются основные признаки ${ }^{51}$. Особое звучание приобретает такая составляющая правовых режимов (фактически стержневой элемент - Г.Б.), как «степень благоприятности (неблагоприятности) для удовлетворения субъектов права», так называемый «информационно-психологический аспект правового регулирования», характеризующийся особым сочетанием правовых стимулов и ограничений.Конечно же, согласно общепринятому подходу, особый настрой, «климат» правового режима зависит от типа (способа) правового регулирования - дозволительного или разрешительного. Что касается выделения стимулов и ограничений в качестве определяющих в рамках режимного регулирования способов правового регулирования, то оно, полагаем, вполне оправданно, но только именно в рамках информационно-психологической теории действия права. В данном случае стимул - это не просто сильный побудительный момент, внутренний или внешний фактор, вызывающий реакцию, а определяющее (создающее магистральное направление) в конкретном правовом режиме средство правового регулирования, основанное на дозволительном типе правового регулирования, побуждающее субъекта права к позитивному поведению и создающее для него режим благоприятствования. В свою очередь, ограничение - средство правового регулирования, основанное на разрешительном типе правового регулирования и позитивных обязываниях, ограничивающее противоправное поведение субъектов (режим неблагоприятствования) и создающее условия для реализации прав и законных интересов других лиц (контрагентов).

Справедливости ради следует заметить, что подобный аспект выделяется и другими, более ранними исследователями данной проблематики. Так, С.С. Алексеев отмечает, что «правовой режим выражает ... наличие известных ограничений и льгот, допустимый уровень активности субъектов, пределы их правовой самостоятельности», и при этом признает «первостепенное значение для освещения правовых режимов различных правовых преимуществ и ограничений» ${ }^{52}$.

Попыткой комплексного осмысления понятия «правовой режим» можно также считать

51 См.: Малько А.В., Родионов О.С. Правовые режимы в российском законодательстве // Журнал российского права. 2001. № 9. С. 19.

52 Алексеев С.С. Общие дозволения и общие запреты. С. 186, 66. определение, предложенное И.Р. Забугиным, как установленный законом и обеспечиваемый государством порядок правового регулирования конкретных областей общественных отношений, выделяющий во временных и пространственных границах те или иные субъекты и объекты права, представленный специфическим комплексом правовых средств, которые создают конкретную степень благоприятности либо неблагоприятности для удовлетворения интересов отдельных субъектов права, и имеющий целью поддержание правового порядка в государстве и обществе ${ }^{53}$. В этом случае при некоторой громоздкости приведенного определения автор все же попытался раскрыть все признаки рассматриваемой категории. Однако, детально указав на одни, вовсе не упомянул другие: не говорится ни о видах правового регулирования, ни о содержательной (структурной) составляющей правового режима.

В продолжение анализа выскажем критическое замечание следующего свойства: по нашему мнению, необоснованным и методологически неверным является предложенное И.Ф. Сюбаревой определение правового режима как вида (или специфики) правового регулирования (курсив наш Г.Б.), который выражен в своеобразном комплексе правовых средств ${ }^{54}$. Как представляется, позиция И.Ф. Сюбаревой во многом обусловлена высказыванием А.В. Малько, изложенным в монографии «Стимулы и ограничения вправе». Приведем его дословно: «Правовой режим с точки зрения информационно-психологического подхода можно рассматривать как специфический вид правового воздействия, который выражен в определенном комплексе правовых стимулов и правовых ограничений» ${ }^{55}$ (курсив наш - Г.Б.).

А.В. Малько в данном случае берет во внимание лишь один аспект правового режима (информационно-психологический), что продиктовано углом зрения вышеназванного исследования. И с точки

53 См.: Забугин И.Р. Понятие правового режима // Правонарушения и юридическая ответственность: Материалы Всероссийской научно-практической конференции. Тольятти, 2009. C. $88-93$.

54 См.: Сюбарева И.Ф. Режимы в российском праве // Вестник Калининградского юридического института МВД России. 2011. № 2 (24). С. 178; Русинов Р.К. Правовое регулирование и его механизм // Теория государства и права / отв. ред. В.Д. Перевалов. М., 2004. С. 153.

55 Малько А.В. Стимулы и ограничения в праве. М., 2003. C. 212 . 
зрения данного аспекта (сочетания в правовом режиме стимулов и ограничений) правовой режим может быть рассмотрен как вид правового воздействия.Во всех же остальных случаях при подобной трактовке правового режима происходит подмена понятий, поскольку вид правового регулирования (так же как и его тип) является самостоятельной научной категорией. Правовой режим даже в самом общем виде представляет собой скорее систему или порядок правового регулирования, а категория «вид» характеризует скорее не сущностную окраску, а видовое своеобразие правовых средств, используемых правовым режимом при регулировании конкретных общественных отношений.

Нельзя умолчать и о том, что существует также опасность излишне «широкого» подхода к определению понятия «правовой режим», когда под ним понимается устойчивый порядок функционирования правовых институтов общества, имеющий общую (доминирующую в рамках данной области общей социально-регулятивной системы) направленность ${ }^{56}$. В указанном определении помимо того, что возникает опасность фактического отождествления рассматриваемого понятия с понятием правовой системы, за широтой подхода теряется сущностная для правовых режимов функциональная (инструментальная) составляющая, а также степень благоприятности (неблагоприятности), необходимая для удовлетворения интересов субъектов права.

Вместе с тем, безусловно, в каждой из вышеперечисленных трактовок правового режима имеются положительные моменты, что позволяет с их учетом и собственного мнения не только выделить основные черты, характеризующие объект исследования, но и систематизировать их.

В результате синтеза основных точек зрения, приведенных проанализированных в предыдущем параграфе, можно констатировать, что правовой режим есть некоторая система ${ }^{57}$, совокупность определенных явлений, призванных обеспечить достижение целей правового регулирования (в том числе беспрепятственную реализацию интересов субъектов права).

\footnotetext{
56 См.: Цыгановкин В.А. Системы социальной регуляции: государственный и правовой режимы // Вестник РГГУ. 2011. № 8 (70). С. 182.

57 Системность и достаточно сложная структура правовых режимов проистекают из рассмотренных концепций, независимо от того, каким содержанием наполняют их авторы понятие правового режима.
}

Здесь надо заметить, что дальнейшее исследование понятия правового режима осложняется в связи с отсутствием так называемого главного, определяющего слова, через которое можно вывести понятие правового режима.

Поэтому мы, вслед за рядом ученых ${ }^{58}$, предлагаем использование функционального подхода, а именно термина «порядок», поскольку восприятие правового режима только как совокупности норм или институтов права существенно обедняет его содержание, превращает его фактически в статическое явление, влечет к отождествлению с более или менее значительной группой правовых норм, закрепленных в нормативно-правовом акте.

Напротив, при употреблении в качестве определяющего слова «порядок» правовой режим превращается в динамическую категорию, в которой можно выделить как его структурные элементы, так и стадии реализации. При этом следует иметь в виду, что речь идет именно об особом порядке правового регулирования, поскольку он вводится в действие по специфическим мотивам, с учетом самобытности социальной ситуации, и не применим в том же виде в каких-либо других сферах.

В результате мы получаем первичную основу для наиболее точного, полагаем, определения: правовой режим - это особый порядок правового регулирования, служащий для беспрепятственной реализации основных целей правового регулирования (в том числе интересов субъектов права).

Продолжая исследование, отметим следующее обстоятельство: поскольку нами выработана лишь основа для определения правового режима, необходимо выделить и другие характерные его признаки, приступим к их установлению и характеристике.

1. Правовой режим, как и любое средство правового регулирования, подлежит обязательному нормативно-правовому закреплению.

Закрепление правовых режимов в нормативно-правовых актах различного уровня посредством письменной формы позволяет:

- четко обозначить комплекс правовых средств, используемых для регулирования (охраны)

\footnotetext{
58 См., напр.: Алексеев С.С. Общие дозволения и общие запреты в советском праве. С. 185; Бабаев В.К., Баранов В.М., Гойман В.И. Словарь категорий и понятий общей теории права. С. 29; Матузов Н.И., Малько А.В. Правовые режимы: понятие и виды // Право и политика: современные проблемы соотношения и развития. С. 14.Шамсумова Э.Ф. Правовые режимы (теоретический аспект). С.7-8; Родионов О.С. Механизм установления правовых режимов российским законодательством. С. 38.
} 
общественных отношений. Это необходимо как для правоприменителя, так и иным субъектам, реализующим право;

- $\quad$ предоставить субъектам, вовлеченным в орбиту правового режима или собирающимся вступить в «режимные» отношения, информацию о правилах поведения в рамках данного режима и тем самым настроить (мотивировать) их на правомерное поведение. Соответственно, стимулом может выступать либо желание реализовать свои права и законные интересы в общерегулятивных правоотношениях, либо избежать возможности привлечения к юридической ответственности в правоотношениях охранительных.

2. Специфическаяцель правового режима - регулирование общественных отношений, создание особого порядка правового регулирования.

Важность исследования целей правовых режимов определяется несколькими причинами. Это позволяет, во-первых, глубже изучить сущность и назначение рассматриваемого явления в системе правового регулирования; во-вторых, осознать ценность режимного регулирования общественных отношений для субъектов права; в третьих, решить проблемы, возникающие на пути эффективного режимного регулирования, поскольку важным критерием эффективности выступает степень достижения нормативно установленных целей.

С нашей точки зрения, под целью правового режима следует понимать предполагаемую или закрепленную государством идеальную модель определенного социального явления (состояния, процесса), достигаемую при помощи реализации правовых средств, входящих в его (правового режима) состав.

Надо сказать, что цели, стоящие перед правовым режимом, весьма разнообразны. Однако единой (комплексной) целью правовых режимов, исходя из их сущности, можно признать оптимальное регулирование общественных отношений, преодоление препятствий, стоящих на пути удовлетворения субъектами (правовыми средствами и способами) своих интересов, создание благоприятного режима для правомерных действий и неблагоприятного режима для противоправных.

Как точно замечает Э.Ф. Шамсумова, «функции правовых режимов, как конкретные, оптимальные направления воздействия права, определяются целями: упорядочить особым способом, организовать определенные общественные отношения, увеличить коэффициент полезности самого права, усовершенствовать механизмы правового регули- рования, и, с другой стороны, предметно-практические, они конкретизированы и связаны с определенной отраслью и определенным объектом» ${ }^{59}$.

Цели правового режима, как правило, формально определены в нормативно-правовых актах, которые являются юридическим основанием введения, функционирования и прекращения действия данного правового режима.

Например, в соответствии со ст. 11 Федерального закона от 06.03.2006 № 35-Ф3 «0 противодействии терроризму» ${ }^{60}$, режим контртеррористической операции вводится в целях пресечения и раскрытия террористического акта, минимизации его последствий и защиты жизненно важных интересов личности, общества и государства на период ее проведения.В данном случае правовые режимы, основанные на ограничениях, обеспечивают эффективное функционирование общерегулятивных правовых режимов.

Что касается отраслевых правовых режимов, их цель, производная от цели общеправовых режимов, определяется предметом, методом, типом правового регулирования той или иной отрасли права.

Таким образом, цель правового режима охватывает содержательную сторону правового режима - основания, причины установления, от которой, в свою очередь, зависит юридическое наполнение режимного пространства - срок действия, территория распространения, объекты правового воздействия, соотношение стимулов и ограничений, юридическая ответственность за нарушение режимных требований и т.д.

3. Особый порядок регулирования, состоящий в особом сочетании правовых средств и способов: дозволений и запретов, позитивных обязываний и рекомендаций ${ }^{61}$, стимулов и ограничений ${ }^{62}$ и т.д.

Именно специфическая комбинация дозволений, запретов и позитивных обязываний при доминировании либо первых, либо вторых и создает особый режим регулирования.

Как верно замечает М.М. Султыгов, «не случайно в рамках правового режима проявляются различные способы правового регулирования, но

\footnotetext{
59 Шамсумова Э.Ф. Указ.соч. С. 103.

60 С3 РФ. 2006. № 11. Ст. 1146.

61 Алексеев С.С. Общие дозволения и общие запреты в советском праве. М., 1989. С. 185.

62 См.: Малько А.В., Родионов О.С. Правовые режимы в российском законодательстве // Журнал российского права. 2001. № 9. С. 19.
} 
в каждом режиме это во многом определяет его специфический настрой - один из способов зачастую выступает как приоритет или доминанта над другим, вследствие чего этот приоритетный способ играет определяющую роль в правовом регулировании и создает при этом особое специфическое направление или удобную для себя атмосферу, «климат» ${ }^{63}$.

В зависимости от того, какие правовые средства доминируют в правовых режимах, они бывают либо создающими преимущества для субъектов права, либо ограничивающими их субъективные права и свободы.

4. Из изложенного выше вытекает следующий признак правового режима: создание благоприятных (неблагоприятных) условий для удовлетворения интересов субъектов права.

Здесь важно подчеркнуть, что правовые режимы, предоставляющие преимущества для субъектов в реализации их субъективных прав и законных интересов, с доминирующим дозволительным началом создают благоприятные условия для удовлетворения интересов субъектов права.

Так, Федеральный закон от 24.07.2007 № 209-Ф3 «0 развитии малого и среднего предпринимательства в Российской Федерации» ${ }^{64}$ создает льготный правовой режим для вышеназванных субъектов, который заключается в установлении специальных налоговых режимов, упрощенных правилах ведения налогового учета, упрощенных формах налоговых деклараций по отдельным налогам и сборам для малых предприятий; льготного порядка расчетов за приватизированное субъектами малого и среднего предпринимательства государственное и муниципальное имущество; мер по обеспечению финансовой поддержки субъектов малого и среднего предпринимательства (курсив наш - Г.Б.) и т.д.

Правовые режимы, основанные на ограничениях (способы правового регулирования - запреты и позитивные обязывания), создают, соответственно, неблагоприятные условия для субъектов.

Например, в соответствии с Федеральным конституционным законом от 30.05.2001 № 3-ФКЗ «0 чрезвычайном положении» ${ }^{65}$ на период действия чрезвычайного положения может предусматри-

63 Султыгов М.М. Конституционно-правовой режим ограничения государственной власти. Дис.... докт. юр. наук. СПб, 2005. С. 45-46.

64 СЗ РФ. 2007. № 31. Ст. 4006.

65 СЗ РФ. 2001. № 23. Ст. 2277. ваться введение следующих мер и временных ограничений: полное или частичное приостановление на территории, на которой введено чрезвычайное положение, полномочий органов исполнительной власти субъекта (субъектов) Российской Федерации, а также органов местного самоуправления; б) установление ограничений на свободу передвижения по территории, на которой введено чрезвычайное положение, а также введение особого режима въезда на указанную территорию и выезда с нее, включая установление ограничений на въезд на указанную территорию и пребывание на ней иностранных граждан и лиц без гражданства (курсив наш - Г.Б.) и т.д.

5. Системный характер правовых режимов, как его признак, проявляется в том, что правовой режим, будучи инструментом в системе правового регулирования, сам является системным образованием, состоящим из подсистем, характеризующихся целостностью, целесообразностью, логичностью, сочетаемостью и т.д.

Поскольку правовой режим представляет собой сложную систему взаимосвязанных элементов, вполне оправданным, с нашей точки зрения, является обращение к системному подходу в изучении объекта исследования, который позволяет раскрыть природу, сущность, назначение правовых режимов, многообразие и взаимодействие их составляющих.

6. Комплексный характер правовых режимов означает, что регулирование, основанное на особом сочетании правовых средств, осуществляется в комплексе.

Взяв за основу высказывание С.С. Алексеева о том, что «правовой режим есть своего рода «укрупненный блок» в общем арсенале правового инструментария, и с этой точки зрения эффективное использование правовых средств при решении тех или иных социальных задач состоит в том, чтобы выбрать оптимальный для решения соответствующей задачи правовой режим, искусно отработать его сообразно специфике этой задачи и содержанию регулируемых отношений» ${ }^{66}$, поясним свою мысль.

Правовой режим - это упорядоченная совокупность (система) правовых средств. В рамках этой системы правовые средства сочетаются строго определенным образом, тесно взаимосвязаны и действуют комплексно, создают определенную атмосферу правового регулирования - степень

66 См.: Алексеев С.С. Общие дозволения и общие запреты в советском праве. С. 185. 
благоприятности (неблагоприятности) для удовлетворения интересов субъектов права.

Правовой режим по своей юридической природе снабжен всеми средствами, необходимыми и достаточными для его функционирования (правила поведения, положительные и отрицательные санкции, включая юридическую ответственность за нарушение режимных требований и т.д.). При этом действие правовых режимов охватывает целый комплекс систем, взятых во временных и пространственных границах (правовые статусы субъектов права, объекты права, юридические факты и т.д.).

7. Особая структура правового режима. Место и роль структуры в существовании всякой социальной системы определяется тем, что именно структура является материальным носителем ее внутренней упорядоченности, обуславливает присущую ей целостность и относительную устойчивость. В этом смысле понятие структуры отражает «статику» системы. Исследование данного статического момента системы обычно называют структурным анализоми предлагают рассматривать его в качестве одного из конкретных, относительно самостоятельных аспектов системного подхода.

Следует при этом иметь в виду, что правильное понимание и плодотворное использование структурного анализа возможно лишь на основе выявления и дифференциации совокупности образующих систему компонентов (системно-элементного анализа), качественная природа которых, их связи и взаимодействия влияют не только на структуру, но и на другие стороны, свойства и особенности той или иной системы.

В структуру правового режима могут быть включены правовые средства различного состава и уровня (простые и комплексные): элементы механизма правового регулирования (правовые нормы, отношения, акты реализации права, юридические факты и т.д.), система гарантий реализации правового режима (в том числе юридическая ответственность за нарушение режимных требований), правовые принципы, цели правового регулирования.

Представляется, что предложенная структура (состав) правового режима наиболее оптимальна, поскольку в ней четко представлены все составляющие (компоненты) исследуемой категории, и она в полной мере отвечает его содержанию.

Суммируя вышесказанное, правовой режимможно определить как особый порядок правового регулирования общественных отношений, основанный на определенном сочетании правовых средств (в т.ч. и способов правового регулирования), гарантий и принципов, создающий благоприятные (неблагоприятные) условия для удовлетворения интересов субъектов права и направленный на достижение оптимального социально-значимого результата.

\section{Библиография:}

1. Алексеев С. С. Общие дозволения и общие запреты в советском праве. М., 1989.

2. Горленко В. А. Режим правового регулирования (теоретико-прикладной аспект). Автореф. дис. ... канд. юрид. наук. СПб, 2002.

3. Забугин И.Р. Понятие правового режима // Правонарушения и юридическая ответственность: Материалы Всероссийской научно-практической конференции. Тольятти, 2009. С. 88-93.

4. Малько А. В., Родионов О. С. Правовые режимы в российском законодательстве // Журнал российского права. 2001. № 9.

5. Матузов Н.И., Малько А.В. Правовые режимы: вопросы теории и практики // Известия вузов. Правоведение. 1996. № 4.

6. Родионов О. С. Механизм установления правовых режимов российским законодательством. Дисс. ... канд. юрид. наук. Саратов, 2001.

7. Ситников А. П. Вопросы соотношения категорий «правовой режим», «правовое состояние» и «правовой порядок» // Вестник Челябинского государственного университета. 2009. № 31 (169). Право. Вып. 21.

8. Султыгов М. М. Конституционно-правовой режим ограничения государственной власти. Дис.... докт. юр. наук. СПб, 2005.

9. Сюбарева И.Ф. Режимы в российском праве // Вестник Калининградского юридического института МВД России. 2011. № 2 (24).

10. Цыгановкин В. А. Системы социальной регуляции: государственный и правовой режимы // Вестник РГГУ. 2011. № 8 (70). 
11. Шамсумова Э. Ф. Правовые режимы (теоретический аспект): Дис. ... канд. юрид. наук. Екатеринбург, 2001.

12. Трегубова Е.В. Дозволение и запрет в административном праве // NB: Административное право и практика администрирования.-2013.-8.-C. 25-56. URL: http://www.e-notabene.ru/al/article_9953.html

13. О.В. Хабибулина Правовой режим государственной службы // LEX RUSSICA (РУССКИЙ ЗАКОН).-2013.8.-С. 847-856.

14. Беляева Г.С. К вопросу о классификации правовых режимов // Актуальные проблемы российского права.-2012.-2.-С. 4-10.

15. Шмидт Т.Н. Понятие чрезвычайного правового регулирования // Право и политика.-2013.-11.-С. 1570-1578. DOI: 10.7256/1811-9018.2013.11.9480.

16. А. С. Лалетина Правовой режим международных трубопроводов на сухопутной территории РФ, континентальном шельфе и исключительной экономической зоне. // Международное право и международные организации / International Law and International Organizations.-2011.-4.-C. 77-84.

17. Купреев С.С. Правовой режим пребывания иностранцев в Российской Федерации в условиях проведения Олимпийских зимних игр 2014 г. в городе Сочи // NB: Административное право и практика администрирования.-2013.-12.-C. 21-34. URL: http://www.e-notabene.ru/al/article_10699.html

18. Афанасьев А.А. Муниципально-правовой режим сельской жизни: понятие и сущность местного самоуправления сельских поселений // NB: Экономика, тренды и управление.-2013.-3.-C. 17-50. URL: http://www.e-notabene.ru/etc/article_7423.html

19. Шмидт Т.Н. Чрезвычайное право как особый комплексный правовой институт // Право и политика.2013.-10.-C. 1250-1254. DOI: 10.7256/1811-9018.2013.10.9604.

20. Ваганов А.А. Правовой режим воздушных судов как предмета лизинга // NB: Экономика, тренды и управление.-2013.-2.-C. 178-192. URL: http://www.e-notabene.ru/etc/article_7505.html

21. Павлов П.В. Особый административно-правовой режим на территории офшорных зон: порядок применения и направления совершенствования // NB: Экономика, тренды и управление.-2012.-1.-C. 6-130. DOI: 10.7256/2306-4595.2012.1.424. URL: http://www.e-notabene.ru/etc/article_424.html.

22. Дубинкина С.Н.. Регулирование международной торговли услугами в рамках Всемирной торговой организации. // Международное право и международные организации / International Law and International Organizations.-2013.-№ 4.-C. 476-487. DOI: 10.7256/2226-6305.2013.4.9316.

23. Берг Л.Н.. Нормотворчество как форма правовой политики. // Право и политика.-2013.-№ 11.-С. 1481-1488. DOI: 10.7256/1811-9018.2013.11.9822.

\section{References:}

1. Alekseev S. S. Obshchie dozvoleniya i obshchie zaprety v sovetskom prave. M., 1989.

2. Gorlenko V. A. Rezhim pravovogo regulirovaniya (teoretiko-prikladnoi aspekt). Avtoref. dis. ... kand. yurid. nauk. SPb, 2002.

3. Zabugin I.R. Ponyatie pravovogo rezhima // Pravonarusheniya i yuridicheskaya otvetstvennost': Materialy Vserossiiskoi nauchno-prakticheskoi konferentsii. Tol'yatti, 2009. S. 88-93.

4. Mal'ko A. V., Rodionov O. S. Pravovye rezhimy v rossiiskom zakonodatel'stve // Zhurnal rossiiskogo prava. 2001. № 9.

5. Matuzov N.I., Mal'ko A.V. Pravovye rezhimy: voprosy teorii i praktiki // Izvestiya vuzov. Pravovedenie. 1996. № 4.

6. Rodionov O. S. Mekhanizm ustanovleniya pravovykh rezhimov rossiiskim zakonodatel'stvom. Diss. ... kand. yurid. nauk. Saratov, 2001.

7. Sitnikov A. P. Voprosy sootnosheniya kategorii «pravovoi rezhim», «pravovoe sostoyanie» i «pravovoi poryadok» // Vestnik Chelyabinskogo gosudarstvennogo universiteta. 2009. № 31 (169). Pravo. Vyp. 21.

8. Sultygov M. M. Konstitutsionno-pravovoi rezhim ogranicheniya gosudarstvennoi vlasti. Dis.... dokt. yur. nauk. $\mathrm{SPb}, 2005$.

9. Syubareva I.F. Rezhimy v rossiiskom prave // Vestnik Kaliningradskogo yuridicheskogo instituta MVD Rossii. 2011. № 2 (24).

10. Tsyganovkin V. A. Sistemy sotsial'noi regulyatsii: gosudarstvennyi i pravovoi rezhimy // Vestnik RGGU. 2011. № 8 (70). 
11. Shamsumova E. F. Pravovye rezhimy (teoreticheskii aspekt): Dis. ... kand. yurid. nauk. Ekaterinburg, 2001.

12. Tregubova E.V. Dozvolenie i zapret v administrativnom prave // NB: Administrativnoe pravo i praktika administrirovaniya.-2013.-8.-C. 25-56. URL: http://www.e-notabene.ru/al/article_9953.html

13. O.V. Khabibulina Pravovoi rezhim gosudarstvennoi sluzhby // LEX RUSSICA (RUSSKII ZAKON).-2013.-8.-C. 847-856.

14. Belyaeva G.S. K voprosu o klassifikatsii pravovykh rezhimov // Aktual'nye problemy rossiiskogo prava.2012.-2.-C. 4-10.

15. Shmidt T.N. Ponyatie chrezvychainogo pravovogo regulirovaniya // Pravo i politika.-2013.-11.-C. 1570-1578. DOI: $10.7256 / 1811-9018.2013 .11 .9480$.

16. A.S. Laletina Pravovoi rezhim mezhdunarodnykh truboprovodov na sukhoputnoi territorii RF, kontinental'nom shel'fe i isklyuchitel'noi ekonomicheskoi zone. // Mezhdunarodnoe pravo i mezhdunarodnye organizatsii / International Law and International Organizations.-2011.-4.-C. 77-84.

17. Kupreev S.S. Pravovoi rezhim prebyvaniya inostrantsev v Rossiiskoi Federatsii v usloviyakh provedeniya Olimpiiskikh zimnikh igr 2014 g. v gorode Sochi // NB: Administrativnoe pravo i praktika administrirovaniya.2013.-12.-C. 21-34. URL: http://www.e-notabene.ru/al/article_10699.html

18. Afanas'ev A.A. Munitsipal'no-pravovoi rezhim sel'skoi zhizni: ponyatie i sushchnost' mestnogo samoupravleniya sel'skikh poselenii // NB: Ekonomika, trendy i upravlenie.-2013.-3.-C. 17-50. URL: http:// www.e-notabene.ru/etc/article_7423.html

19. Shmidt T.N. Chrezvychainoe pravo kak osobyi kompleksnyi pravovoi institut // Pravo i politika.-2013.-10.-C. 1250-1254. DOI: 10.7256/1811-9018.2013.10.9604.

20. Vaganov A.A. Pravovoi rezhim vozdushnykh sudov kak predmeta lizinga // NB: Ekonomika, trendy i upravlenie.-2013.-2.-C. 178-192. URL: http://www.e-notabene.ru/etc/article_7505.html

21. Pavlov P.V. Osobyi administrativno-pravovoi rezhim na territorii ofshornykh zon: poryadok primeneniya i napravleniya sovershenstvovaniya // NB: Ekonomika, trendy i upravlenie.-2012.-1.-C. 6-130. DOI: 10.7256/2306-4595.2012.1.424. URL: http://www.e-notabene.ru/etc/article_424.html.

22. Dubinkina S.N.. Regulirovanie mezhdunarodnoi torgovli uslugami v ramkakh Vsemirnoi torgovoi organizatsii. // Mezhdunarodnoe pravo i mezhdunarodnye organizatsii / International Law and International Organizations.-2013.-№ 4.-C. 476-487. DOI: 10.7256/2226-6305.2013.4.9316.

23. Berg L.N.. Normotvorchestvo kak forma pravovoi politiki. // Pravo i politika.-2013.-№ 11.-C. 1481-1488. DOI: 10.7256/1811-9018.2013.11.9822. 